\title{
Implementation of Situational Leadership in Educational Organizations
}

\author{
Maisyaroh \\ Department of Educational Administration \\ Universitas Negeri Malang, Indonesia \\ maisyaroh.fip@um.ac.id
}

\author{
Ali Imron \\ Department of Educational Administration \\ Universitas Negeri Malang, Indonesia \\ ali.imron.fip@um.ac.id \\ Burhanuddin \\ Department of Educational Administration \\ Universitas Negeri Malang, Indonesia \\ burhanuddin.fip@um.ac.id
}

\author{
Juharyanto \\ Department of Educational Administration \\ Universitas Negeri Malang, Indonesia \\ juharyanto.fip@um.ac.id
}

\author{
Rachmat Satria \\ Department of Educational Management \\ Universitas Negeri Malang, Indonesia \\ satriarachmat7@gmail.com
}

Indah Puspitaningtyas

Department of Educational Management Universitas Negeri Malang, Indonesia indahpuspitaningtyas0302@gmail.com

\begin{abstract}
The writing of this article aims to find out situational leadership in educational organizations. The writing of this article uses a literature study approach by examining theories that relevant to the principal's leadership with a situational leadership model (contingency). Based on the studies conducted it can be seen that: (1) the contingency model is said to be effective depending on the conditions and situations between leadership behavior and the maturity level of its subordinates; (2) leadership through a situational approach can affect the level of success of a leader in streamlining the performance of his subordinates; (3) contingency the model is taken into consideration in situations that help a leader in deciding leadership styles; and (4) a situational approach is applied by a leader because there are various possibilities of different situations and behaviors in educational organizations.
\end{abstract}

Keywords: situational leadership, principal, leadership model

\section{INTRODUCTION}

The 21 st century education world is experiencing rapid development and progress with various innovations and the results of scientific research that groups various approaches in leadership theory. The role of a good and competent leader in carrying out his leadership is needed to realize the vision and mission of an institution. The leader is expected to be able to direct and move all his subordinates in order to carry out their duties optimally and clearly in accordance with the responsibilities of each individual or group of organizations. Likewise, the personality of a leader determines a good policy direction for the organization, internal and external factors that must be possessed by the visionary principal.

Specifically in education, the effectiveness of school principals determines the pace of institutional change as well as competitive innovation efforts in future global competition. The principal's leadership by giving clear instructions to his subordinates, the subordinates will voluntarily and responsibly carry out the organizational duties [1]. The headmaster understands the development of the condition of his organization so that he can adapt to the leadership style that will be applied, one of the leadership styles that is implemented in the world of education using a situational approach. This approach examines the characteristics of members to match leadership behavior with the maturity level of their subordinates.

Effective leadership behavior depends on a variety of variables so that a leader should adapt to the conditions of the situation contained in the organizational environment. Likewise, the implementation of leadership style depends on the factors of the situation, the characteristics of organizational members and the organizational environment [2]. The contingency approach is able to analyze each existing situation as an effective reference for leaders in determining their leadership style [3].

Situational leadership uses existing leadership models to achieve leadership goals that are appropriate to the desired situation and achieve maximum goals. This concept focuses on adjusting the force to the reality of the actual conditions on the ground. Some situational approach models that have been developed by experts include: (a) continuum model; (b) contingency model; (c) life cycle; and (d) path goal theory. The principal's personality and social skills are needed to influence the behavior of others so that they can improve the performance competencies of educators in achieving common goals. Briefly concluded that the leadership style is intended to influence, direct and control the behavior of others to achieve common goals.

\section{METHOD}

The writing of this article aims to find out situational leadership in educational organizations. The writing of this article uses a literature study approach by examining theories that are relevant to the principal's leadership style in educational organizations. This article is expected to be a reference in the implementation of situational leadership styles in educational institutions in making teacher performance effective in schools.

\section{RESULT}

Based on the results of a literature study on the implementation of situational leadership in educational 
organizations that the effectiveness of situational leadership depends on the situation and behavior of organizational members, this approach seeks to examine the characteristics of members to adjust between leadership behaviors with the maturity level of their subordinates. The leadership style that is applied must be viewed from several aspects such as the environment, work spirit and characteristics of each subordinate who has different backgrounds that differ from one another, so that the merits of an organization can be an indicator value for the success of various style concepts applied in his leadership. An effective situational leadership style can improve the performance of teachers, by understanding the various needs will create a conducive situation at work and move their performance in accordance with the goals set in educational institutions.

\section{DISCUSSION}

\section{A. Basic Concepts of Situational Leadership}

The concept of situational leadership theory comes from several forms of resistance of psychology and sociology which emphasizes the form of situational analysis [4]. This means that effective leadership must be flexible enough to adapt to different environments and situations. Some classifications of leadership determination, include: (1) organizational structural devices (size, hierarchical structure, and formalization); (2) organizational climate (openness, participatory, group atmosphere); (3) role characteristics (strength of position, type and difficulty of tasks, procedural rules); and (4) subordinate characteristics (knowledge and experience, tolerance for diversity, responsibility and power) [5].

This concept was first introduced by Fred Fiedler as one of the first models in leadership research which is theoretically multi-level and methodologically multisource [6,7]. The situational leadership approach emphasizes the ability of leaders who are able to act with useful behavioral guidelines and are based on the results of a combination of abilities in all situations.

Another source states that the development of situational theory is a refinement of previous theories. Based on this theory, a leader can diagnose the situation well, choose a leadership style and apply it appropriately. With the hypothesis that (1) the quality of the leader and his leadership depend on the situation of the group; and (2) the quality of individuals in overcoming situations is a legacy from previous leadership who succeeded in overcoming the same problem [4].

Four dimensions developed in situational leadership. First, managerial skills include social skills, experience, motivation, and research on appreciation provided by organizations. Second, job characteristics in the form of challenging tasks will make a person more enthusiastic and the level of group collaboration influences the effectiveness of the leader. Third, cultural characteristics include organizational culture, policy, bureaucracy are factors that influence the effectiveness of its leaders. Fourth, job characteristics include personality, needs, skills, experience of subordinates will influence the style of leadership. Effective leadership is seen in the interactions between situations and leader behavior [8].

The leadership of an organization becomes one of the important factors in making decisions for progress, changing situations and internal and external conflicts required an effective role of a leader in solving various field problems. Effective leaders have advantages including intelligence level, situation sensitivity, effective work, initiative, self-confidence, individuality, technical and professional competence, effort, high ethical standards, flexibility and vision [9]. These factors are important traits that must be owned by a leader in running his leadership; the characteristics of leaders will determine the success of educational institutions. Characteristics of leadership traits include abilities, harmonious, physical relationships, imagination, patience and hard work [10]. In short, the nature of leadership becomes a basic reference in the process of fostering and directing others, leaders have a good vision to determine the effectiveness of a leadership. Different situations in each organization will determine the leadership behavior in accordance with the conditions at the institution. The situational approach becomes the basis of consideration for principals in influencing and directing education personnel in achieving national education goals.

\section{B. Situational Leadership Models}

Situational leadership uses existing leadership models to achieve leadership goals that are appropriate to the desired situation and achieve maximum goals. The assumption is that society is formed by individuals and traces of cultural heritage [11].

\section{Continuum Model - Tannenbaum and Schmith}

The continuum model leadership is based on the pattern of decision making. Decision-making behavior departs from the following views: first, leader-oriented; second, oriented towards subordinates / members. Seven leadership patterns identified by Tannenbaum and Schmith include: (1) leaders limit the activities of their members. leaders make and announce decisions to their members (telling); (2) leaders provide opportunities for members to make decisions (selling); (3) the leader gives the problem and asks its members to propose solutions to the problem then the leader makes a decision; (4) tentative leaders present decisions for groups and decisions can still be changed by groups; (5) the leader points out the problem and asks the group to make a decision (consulting); (6) the leader makes the decision and assures the group that the decision is right; (7) leaders allow their subordinates to make decisions according to predetermined limits (joining) [4].

The Continuum model has three main factors which form the basis for the choice of leadership patterns. First, the strength of the manager has a great influence on the success of an organization. The strength of a leader can be the strength of his personality, experience, and the value that is applied in life. Second, strength from below the leader in this case is a member in an organization. Third, the strength in a situation formed by the conditions of interaction between leaders and their members, organizational climate is very influential in the interaction between leaders and their members.

\section{Contingency Model - Fiedler}

The contingency leadership model emerged after the behavioral approach. Contingency theory states that leadership effectiveness depends on the relationship 
between personality characteristics and leader behavior with situational variables. These variables are task structure, power position, skills and attitudes of subordinates. So, there is no "best" style in a variety of different situations [5]. This leadership model seeks to predict which types of leaders are effective in different types of situations.

This leadership model considers that the most effective leadership style depends on the situation at hand and the change in style is not a difficult thing. Three variables are grouped by Fiedler. First, the task structure; Second, leader member relationship; Third, position power includes legitimate power, reward power, positive power, referent power, information power.

The three groups of variables above can lead to three kinds of situations that will later be faced by leaders. First, the leader is well received by subordinates, the task is clearly structured, and the leader's strength is also good in actualizing his leadership. Second, the leader is not well received by subordinates, the task is not clearly structured, and the strength of the leader is also not good in actualizing his leadership. Third, the situation in the middle between accepted and not accepted by his subordinates.

However, there are several choices of styles that can be chosen according to the situation formed in the group, including: (1) the leader orientation style that emphasizes the task. This style can be applied to situations that are very pleasing to the leader or to situations that are very unpleasant to the leader. In situations that are very pleasing to the leader, the task can still run well because it is well structured. And in a situation that is very displeasing to the leader, decision making and assigning tasks must still be done. A leader who makes a wrong decision is still far better than a leader who in an unpleasant situation does not make a decision; and (2) human relations orientation style. These conditions are suitable for the leader to apply when he is in the midst of his subordinates. For example, if a member has good professionalism, then the leader is not good, certainly will not be accepted by its members, because the leader ignores his own duties.

Fiedler developed personality measurements used in measuring leadership styles. The measurement of personality is called the Least Prefer Co-Worker (LPC) scale. The LPC scale contains 16 items that have two poles. The respondent is asked to choose with whom he will work together. Then describe the person in the form of a scale. Each scale is given a score of one to eight. A score of eight for someone he really likes. Then the scores are added up to find out the value of a person's LPC [5].

Fiedler also predicted that a leader with low LPC was a leader who prioritized task orientation. However, this would be better or more effective than with a leader with LPC hight who prioritizes orientation to human relations or good relations with others if the situation control is low or very high. Conversely, leaders with high LPC will be more effective than low LPC leaders if the situation control is moderate [4].

\section{Life Cycle Theory - Hersey and Blanchard}

Hersey \& Blanchard developed an effective situational leadership model by combining the level of maturity of subordinates with the behavior patterns of their leaders. The four levels of maturity of subordinates include, (1) M1: subordinates are unable and unwilling or do not have the confidence to complete the task; (2) M2: subordinates are unable but have the will and confidence to be able to complete the task; (3) M3: capable subordinates but do not have the will and do not have the confidence to complete the task; (4) M4: subordinates are able and have the will and confidence to complete their tasks [4].

Hersey \& Blanchard also developed four styles of leader behavior in problem solving and decision making. The four styles referred to include, Style 1 (Telling): the leader gives instructions and oversees his subordinates in carrying out their duties; Style 2 (Selling): the leader explains his decision and opens up opportunities for his subordinates to ask questions when things are unclear; Style 3 (Participating): the leader provides an opportunity for subordinates to convey ideas as material for consideration in decision making; and Style 4 (Delegating): the leader gives decisions and executes tasks to his subordinates because the ability and enthusiasm of his subordinates to have a great deal of accomplishing tasks [6].

\section{Path Goal Theory - House and Mitghell}

This theory explains the influence of leadership behavior on the expectations of subordinates. The expectations of subordinates often relate to the level of morale, motivation, satisfaction and pride in their work. Subordinates often hope that the leader can help him in achieving his goals [4].

Path Goal Theory visualizes the four leadership orientations as follows: (1) instrumental, this instructive or directive leadership is the same as an autocratic type of leadership. The leader will convey to his subordinates the rules, decisions and tasks that must be completed; (2) supportive, supportive leadership. A leader will show concern for his subordinates in all matters aimed at facilitating subordinates in completing their duties; (3) participative, participatory leadership, i.e. leaders will ask for and provide opportunities for their subordinates to make decisions; (4) achievement oriented, leadership oriented to achievement, a leader will set all forms of rules and limit subordinates in participating with the aim that the bahawan be convinced to be able to carry out their duties and achieve goals to the maximum.

\section{Implementation of Situational Leadership in Education}

Leadership in organizational institutions requires a pattern or style of a leader to be able to achieve the goals set by the institution in the future. Each educational institution has different views in dealing with various organizational problems, so leadership is needed to achieve the main goal with the assumption that the behavior and characteristics of leadership can influence and invite others. The headmaster tries professionally to improve teacher performance through ideas, participative, giving understanding, motivation and straightening misunderstanding directly or non-directly [12].

Leaders' skills are needed in implementing various styles so that all subordinates are able to work in 
accordance with established procedures, applied leadership style in terms of several aspects such as the environment, work spirit and characteristics of each subordinate who have various backgrounds that vary from one another, so that the merits of an organization can be an indicator value for the success of various style concepts that are applied in its leadership.

A good leader can diagnose all the conditions and circumstances of his subordinates in order to be able to direct and guide them effectively. Understanding a leader of the needs can foster subordinates to work more optimally also helps a leader in choosing the most appropriate leadership style which is an influential aspect in making decisions for the achievement of organizational goals.

Situational leadership theory is based on the leadership style where a leader must pay attention to the situation of his subordinates in an organization; the application of leadership strategies is based on the situation in the field because the leadership style must be adapted to the different situations in each organization [13]. This model is a certain key factor in determining the situation and circumstances of followers who must be encouraged. Contingency also determines certain factors from several leadership approaches that produce specific combinations of predictable outcomes, including member involvement, dependence, creativity and psychological empowerment [14].

Leadership using a situational approach can also influence the level of success of a leader in making the performance of subordinates effective. In addition, it can also be taken into consideration in situations that help a leader in deciding the style used in the leadership process. For example, the principal gives an intrusion to the education staff in the school environment trying to pay attention and consider all the situations that exist in the school both in terms of their level of maturity and in terms of group behavior, giving instructions given by the principal to the teaching staff who have graduate education have different behavioral patterns of giving instructions to high school graduates. Principal's leadership behavior in institution $X$ will be different in the pattern of leadership behavior when he becomes a leader in institution $\mathrm{Y}$ which is caused by the different situation in each institution. The results of other studies mentioned that the training method with a contingency approach shows leadership effectiveness related to overall task performance, training programs encourage the level of motivation of members to perform better [15].

Leadership style can be identified through several factors that will affect a leader, including: (1) the personality of the leader, (2) the personality of subordinates, (3) personality between leaders, (4) organizational structure of the organization, (5) organizational vision, (6) organizational activities, (7) experiences, norms and values contained in the culture of the organization, (8) level of graduate education, (9) organizational policies, (10) technology, (11) applicable laws and regulations, and (12) economic, political and security conditions that are found in the organization [16].

Furthermore, leadership style with situational approach focuses on applying the most effective style to a particular situation [17]. In other words, the organizational situation faced by the leader becomes an important aspect in the success of a leadership. In general, a situational approach is applied by a leader because there are various possibilities of different situations that must be faced by adjusting the leadership behavior with the situation of the organization they lead.

The various approaches contained in leadership theory form the basis for the development of leadership styles in leading an organization, an understanding of leadership styles and models for leaders of educational institutions helps in choosing leadership patterns that are considered good and effective in managing by adjusting to the conditions found in institutions he led, because every educational institution has different problem paths, it requires several applications of different leadership styles. An indicator of the success of a leader in this case is how he is able to adjust to the current situation [18]. In a more detailed formulation, the contingency model has a conceptual work context in looking at conditions that can trigger change in the organization which includes leadership knowledge, training, and job rotation. Contingencies dynamically bring about appropriate changes in leader behavior and performance [19].

On the other hand, leaders can also provide opportunities for their subordinates so they can hone their skills in doing their respective jobs, and improve their competencies for the better. School principals must provide encouragement and motivation for teachers in carrying out their main tasks in teaching, showing good leadership traits in accordance with norms and values contained in education so that they can serve as good role models for teachers and students in the school environment. Conversely, if the principal takes the wrong step in behavior then it will negatively impact the teacher, thereby reducing their ability to complete their work. The application of the situational approach seeks to find a middle ground by adjusting to the needs of teachers in developing and enhancing abilities in teacher performance to achieve educational goals.

Every educator needs to pay attention and adjust to the behavior of students both individually and in groups. Knowledge model and leadership style for educational leaders based on the characteristics, behavior and situation are seen as important for the progress of an institution in line with the vision and mission that have been set together.

The leader influences the success factor of the sustainability of the education process, the ability and skills of the principal will determine the policy achievement of the goals of the educational institution. Principals are required to be able to apply situational leadership in the educational institutions they lead so that the working mechanism of the teachers becomes more optimal, the guidance and direction provided by the leader becomes a relationship that affects the level of readiness of the teachers in carrying out their duties.

Situation analysis and identification of the characteristics of the teachers will be the basis for the application of situational leadership theory so that it can overcome various forms of problems with the right decision. The results of the study indicate that the implementation of situational leadership style by the headmaster of Wamena 1 Junior High School where this 
situational style helps the principal in embracing all parties, being fair and providing motivation to teachers in accordance with established competency standards so that the impact on improving the quality of education in the school [20].

It can be concluded that the selection of effective situational leadership styles can improve the performance of teachers, by understanding various needs will create a conducive situation at work and move their performance in accordance with the goals set by the educational institution. Good leadership will determine the form of performance behavior of each subordinate.

\section{CONCLUSION}

Based on the results of discussions related to situational leadership theory, it can be concluded that the concept of situational leadership theory is an approach taken by a leader especially in the scope of the school is the principal who emphasizes the ability to be able to act with useful behavioral guidelines and based on the results of a combination of abilities in all situations.

Various situational leadership models such as: (a) continuum model, (b) contingency model, (c) life cycle, (d) path goal theory. In the situational leadership model has several views on the leadership style that can be carried out by a leader in dealing with situations to control members and their organizations in achieving goals.

Implementation of situational leadership in education or its application by a leader must balance the various possibilities of different situations that must be faced by adjusting leadership behavior with the situation of the organization he leads. For example: (1) the personality of the leader, (2) the personality of subordinates, (3) personality between leaders, (4) organizational structure of the organization, (5) organizational vision, (6) organizational activities, (7) experiences, norms and values contained in the culture of the organization, (8) the level of graduate education, (9) organizational policies, (10) technology, (11) applicable laws and regulations, and (12) economic, political and security conditions found in the organizational environment. Situational leadership style is reviewed through many aspects both in terms of personal, subordinate members, the environment in the organization, and also the environment from outside the organization.

\section{REFERENCE}

[1] A. S. Hamdi, Metode Penelitian Kuantitatif Aplikasi Dalam Pendidikan. Yogyakarta: Deepublish, 2014.

[2] T. H. Handoko, Manajemen. Yogyakarta: Badan Penerbit Fakultas Ekonomi UGM, 1992.

[3] J. A. F. Stoner and R. E. Freeman, Management Englewood Cliffs, New Jersey: Prentice-Hall A Division of Simon \& Schuster, Inc, 1992.

[4] Mustiningsih, Pengantar Kepemimpinan Pendidikan. Malang: FIP Universitas Negeri Malang, 2013.

[5] H. Soetopo, Kepemimpinan Pendidikan. Malang: FIP Universitas Negeri Malang, 2010.

[6] A. Haris. (2013) Buku Perkuliahan Kepemimpinan Pendidikan Paket 1 s/d 12. [Online]. Available: http://digilib.uinsby.ac.id/20060/1/9.\%20Kepemimpinan\% 20Pendidikan\%20Abd\%20Harris..ok.pdf
[7] R. Ayman, M. C. Martin and F. E. Fiedler, "The Contingency Model of Leadership Effectiveness: Its Levels of Analysis," The Leadership Quarterly., Vo. 6, pp. 147-167, 1995.

[8] Wahyudi, Kepemimpinan Kepala Sekolah dalam Organisasi Pembelajar (Learning Organization). Bandung: Alfabeta, 2015.

[9] A. J. Dubrin, Foundations of Organizational Behaviour an Applied Perspective, London: Prentice-Hall International, Inc, 1984

[10] N. Fatah, Landasan Manajemen Pendidikan, Bandung: PT Remaja Rosdakarya, 1996.

[11] I. Huvila, J. Eriksen, Hausner, Eva-Maria, Jannson, and Ina-Maria, "Continuum Thinking and The Contexts of Personal Information Management," Information Research: An International Electronic Journal., Vol. 19, March 2014.

[12] N. Rohmah and Karwanto, "Keterampilan Manajerial Kepala Sekolah Dalam Peningkatan Kinerja Guru (Studi Kasus Di SMP Negeri 26 Surabaya)," Jurnal Inspirasi Manajemen Pendidikan., Vol. 4, pp. 141-151, 2014.

[13] N. Purwanto, Administrasi dan Supervisi Pendidikan. Bandung: PT Remaja Rosdakarya, 2016.

[14] D. H. Jeffery and S. K. Yoho, "Toward a Contingency Model of Leadership and Psychological Empowerment: When Should Self-Leadership Be Encouraged?, Journal of Leadership \& Organizational Studies., Vol.11, pp. 6583, 2005.

[15] A. Leister, D. Borden and F. E. Fiedler, "Validation of Contingency Model Leadership Training: Leader Match," Journal Academy of Management., Vol. 20, pp. 464-470, 2017.

[16] Sutarto, Dasar-Dasar Kepemimpinan Administratif. UGM Press, Yogyakarta, 1986.

[17] A. Majir, Perkembangan Manajemen Pendidikan. Jakarta: Cipta Restu Fellynda, 2012.

[18] J. R. William, Managerial Effectiviness, New York: Mc Graw Hill Book Company, 1996.

[19] F. E. Fiedler, "The Contingency Model and the Dynamics of the Leadership Process," Advances in Experimental Social Psychology., vol. 11, pp. 59-112, 1978.

[20] S. Aisyah and S. Takdir, "Implementasi Gaya Kepemimpinan Situasional Kepala Sekolah di SMPN 1 Wamena Kabupaten Jayawijaya," Jurnal kepemimpinan dan Pengurusan Sekolah., vol. 2, pp. 119-132, 2017. 